WASHINGTON, D.C.-This year Texas' San Antonio-Austin corridor will develop into the U.S. biotechnology capital. DNA probe- and monoclonal antibody-based diagnostic kits will arrive on the market in 1985 . And throughout the year debate over the regulation of biotech will escalate. These are the predictions expounded by a new 63-page book/pamphlet from the Naisbitt Group (Washington, D.C.).

One of the ten trends that The Year Ahead pinpoints is the emergence of biotechnology. Social forecaster John Naisbitt and company report that Texas business and government leadership-in a concerted effort to diversify away from oil dependency-has what it takes to come out ahead in the multi-state scramble to attract biotechnology industry. Mild weather, a favorable financial environment, recumbent unionism, low taxes, and a burgeoning infrastructure of biomedical technology will combine to boost Texas to the forefront of biotech innovation, the report states.

Right behind San Antonio-Austin will be the Washington-Baltımore area, says the Naisbitt Group. This region boasts impressive federal funding-as compared to 'Texas' strong private support-and proximity to major universities and research centers.

While regions like San Francisco, $\mathrm{CA}$, and Cambridge, MA, may have the more established biotechnology clout right now, Texas will exhibit the fastest growth this year and warrant the title of U.S. biotechnology capital, says Corrinne Kuypers-Denlinger, editor-in-chief of The Year Ahead. Also, these up-and-coming regions will spend more money than established areas to attract biotechnology. "I think we'll see the fastest growth there," she adds, "but more important is that biotechnology is our new frontier."

In John Naisbitt's recent maga-hit, Megatrends, he calls gene splicing "more important than atom splitting-unless, of course, we blow ourselves up." He adds, "The next twenty years will be the age of biology in the way that the last twenty years have been the age of microelectronics."

In the new publication, this enthusiasm continues: "One day a manremade microbe will consume quantities of copper ore and excrete pure copper. Toxic PCBs will be wolfed down by microbes that exist to eat the hazardous waste product. Biological

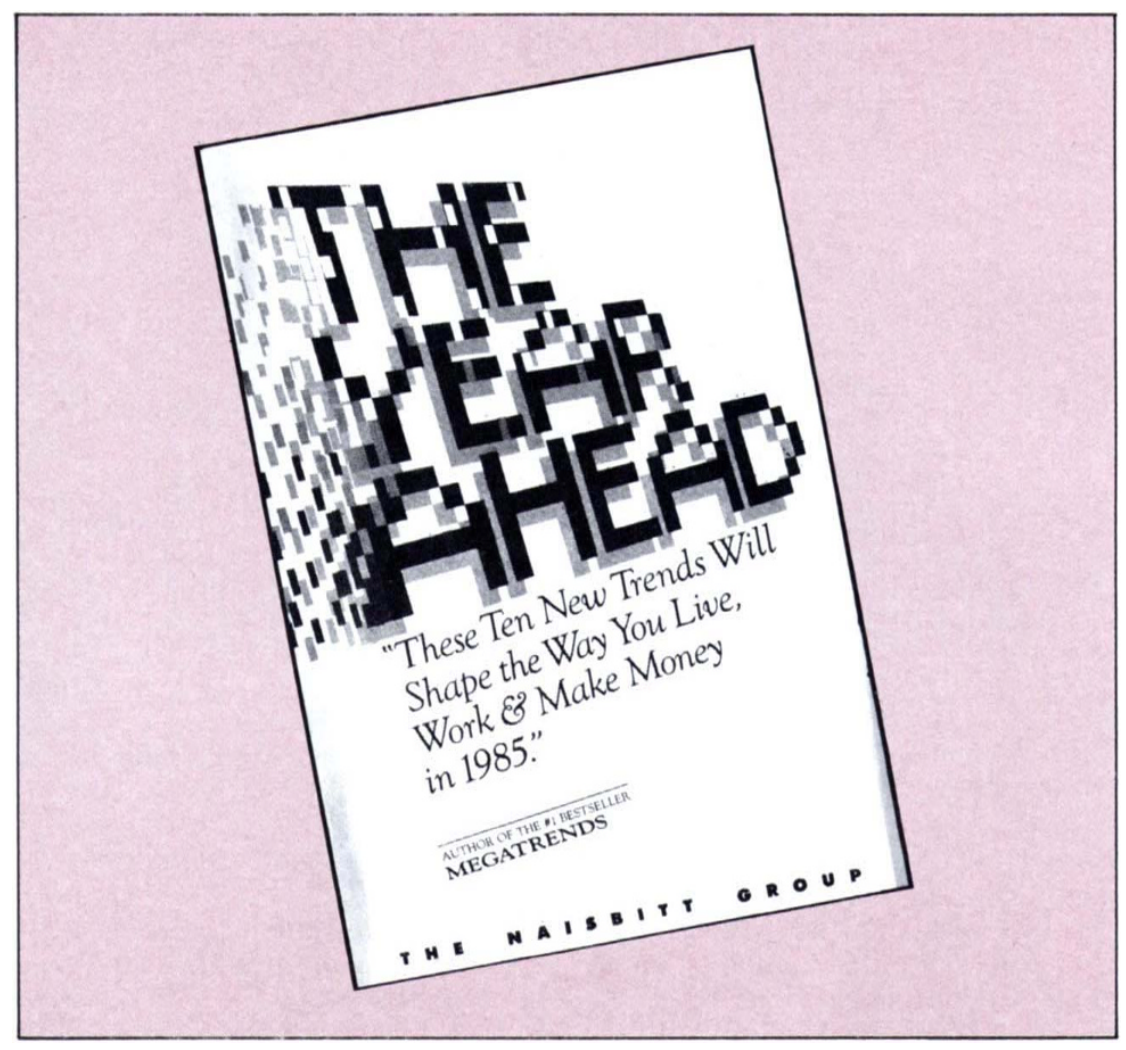

refineries one day will create a pig that yields more chops, a drug that cures cancer, and a plant that frightens insects away." The report predicts that at least two-thirds of the nation's industries will gain from biotechnology and points to $\$ 50$ billion in annual biotech sales by the year 2000 .

Some of the authors' judgments may, however, be open to question: "Already," the book states, "Maryland-based Genex Corp., one of the country's five biggest biotechnology firms, has developed a biological drain cleaner for household use. Genetic engineering created a tiny microbe with an insatiable appetite for human hair and nothing else." A representative from Genex counters that the company's drain cleaner is for industrial (not household) use, that it is an enzyme preparation (not the microorganism itself), and that the microbe is not genetically engineered.

Another result of the growth of biotech, according to Naisbitt Group, will be the creation of jobs. Even the often-predicted shake-out of start-up firms will do little to stem this rising tide as service and administration positions increase, says Kuypers-Denlinger. Medical applications will give way to agricultural advances and then to chemicals, pollution control, and energy.
As with other technologies, the Naisbitt Group foresees a societal counterbalance occurring as biotechnology takes off-this is the "high tech/high touch" phenomenon referred to in Megatrends. As biotech allows doctors to prolong people's lives, the debate over the quality of life and the quality of death will intensify, says Kuypers-Denlinger.

Another rebound against biotechnology will be regulatory. "There is growing concern," The Year Ahead states, "that in this highly competitive industry, voluntary guidelines may not be sufficient to protect the public from unknown and indeterminable dangers." Adds Kuypers-Denlinger, "I think there is going to be a push for mandatory guidelines." She predicts that the brunt of the regulation will fall eventually on state authorities, with Federal intervention occurring only in isolated instances. Because environmentally released microbes will not abide by strict state boundaries, however, she suggests that states may band together into coalitions for a regional approach, much as they regulate water use.

\section{-Arthur Klausner}

Copies of The Year Ahead are available through The Naisbitt Group, 1101 30th St. NW, Washington, D.C. 20007. 